\title{
Commodity money in the Spanish Reinos de las Indias
}

\begin{abstract}
Despite being throughout the Modern Age the world's currency mint, in the Ultramarine territories of the Hispanic monarchy survived pre-Hispanic monetary uses, and also they had to resort in certain areas where the metallic currency was scarce or there was no fractional currency in circulation to other forms of payment. This article analyses these different forms of payment, often goods of daily use in the territories where they were used.
\end{abstract}

Keywords: commodity money, currency, monedas de la tierra, hispanic-american history, anthropology

Volume 4 Issue I - 2019

\section{Pedro Damián Cano Borrego}

Department of History and Arqueology, Universidad

Complutense de Madrid, Spain

\author{
Correspondence: Pedro Damián Cano Borrego, Doctor \\ Department of History and Arqueology, Universidad \\ Complutense de Madrid, Spain, Tel 0034913651868 , \\ Email pietroyanaky@telefonica.net
}

Received: January 26, 2019 | Published: February 14, 2019

\section{Introduction}

Already since 1493 the Indian Cabildos ${ }^{1}$ pressed the Spanish sovereigns to create mints in the Indies. The biggest obstacle was the lack of specialized personnel, given that those who crossed the ocean preferred to devote themselves to silverware, a much more lucrative activity than to mint coins. The Crown also distrusted the licenses to private individuals, given the bad result that this practice had given in the emissions under medieval Castile. This meant, as stated by Céspedes del Castillo, that most of the transactions were made on credit, compensating debts and liquidating the balances with gold and silver by weight, not coined. The shortage of currency, which had to be imported from the Iberian Peninsula in the first half of the $16^{\text {th }}$ century, made the reales ${ }^{2}$ of silver arriving in Indian territory disappear quickly from the circulation, being treasured by the wealthy classes, or returned as payment of commercial transactions. The coined real had superior estimation in the Spanish Indies to that of the Peninsula by $30 \%$, given that it was worth 44 maravedies $^{3}$ instead of 34. Carson ${ }^{1}$ claimed that there were numerous complaints about this overvaluation in Santo Domingo, even after the period in which Antonio de Mendoza, Viceroy of New Spain, introduced a regular production of silver. Quoting Herrera, he gathered that before 1510 there was no gold coin circulating in Santo Domingo, but they were false castellanos $^{4}$ and ducados ${ }^{5}$. The existence of this overprize, which corresponded with the expenses of transport, was one of the reasons, together with the distrust of the Monarchy for the above causes, of the delay during some years the establishment ultramarine mints.

${ }^{1}$ The cabildos were municipal corporations created in the Canary Islands and later in the Indies, America and the Philippines by the Spanish Monarchy for the administration of the cities.

${ }^{2}$ The Spanish real is a silver coin of 3.35 grams that began circulating in Castile in the $14^{\text {th }}$ century and was the base of the Spanish monetary system until the mid-nineteenth century. Its multiple, the piece of eight, peso, duro or dollar, is in the origin of the currencies in Latin America and the United States dollar.

${ }^{3}$ The maravedi was an ancient Spanish coin used between the $12^{\text {th }}$ and 19 th centuries, which were also used as a unit of account.

${ }^{4}$ The castellano was a gold coin coined in Spain in the $14^{\text {th }}$ century. I was most commonly called gold peso and sometimes only peso. It was worth a sixth of an ounce of gold. 72 Castellanos composed a 12-ounce Roman pound, and corresponded to 14 reales and 14 silver maravedís, which amounted to 7 pounds and 5 tornese salaries. When ceased to be coined, in 1497, it remained as a unit of weight in the payments.

${ }^{5}$ The Spanish gold ducado has a weight of $3.6 \mathrm{~g}$, it is the single currency of gold and was one of the units of account during the sixteenth and seventeenth centuries
Due to its high intrinsic value, it highlighted in the early stages the use as a currency of the native gold found in the golden operations in the Great Antilles and the silver found in the continent, which circulated habitually in raw, which meant a flexible adaptation of the current monetary system in Castile. With this the obvious problems arose to determine the true value of these pieces of gold and silver without paying taxes, normally alloyed with other metals and even fraudulently falsified with copper alloy when converting it into bars. The Castilians called guanin to gold under the law, alloyed with copper in proportions close to $50 \%$, which received the names of $t u o b$ between the Tainos and caracoli among the Caribs. It was also used for the rescues the brass, a variable alloy of gold and silver obtained in the mines, and the chafalonía, copper alloy with little gold. It must be taken into account that for the Indians of the Caribbean copper was the most valuable of the metals, in an estimated amount before the discovery of 1 to 4 with respect to the gold.

From its extraction areas in the north of the current Chile its trade extended to Central America and the Caribbean area, which suffered scarcity of this metal by the monopoly exerted by the Incas on its transport and commercialization. Its massive introduction by the Spaniards, in the form of copper coin, vessels or quincallas, the exploitation of the deposits of Balsas River from 1524 and its commercialization throughout the area carried out the rapid and irreversible depreciation of this metal. In continental territory, and more specifically in New Spain, the first native Hispanic currency coined was the gold peso of Tepuzque. According to Gil Farrés, ${ }^{2}$ Tepuzque would be the Spanish version of Teputzli, copper in the Nahuatl language. Vázquez Pando (1995:1685) collects the testimony of Bernal Díaz del Castillo on these pesos. The Viceroy Mendoza, by ordinance of June 15,1536 , established that its valuation was fixed in eight reales, one dollar, and for Pradeau its circulation lasted from 1522 until the reign of Felipe II, although from 1536 they were collected to recover the gold which they contained and to turn it into currency.

In early New Spain, The most small commodity money was the cocoa bean, and a thousand six hundred grains amounted to a gold peso of Tepuzque. Mar ${ }^{3}$ stated that cocoa beans had been the main currency of the ancient Mexicans, which in some areas were continued to be used in the Hispanic era and were still in use in 1847, when the US. Army invaded Mexico. Carson ${ }^{1}$ detailed that according to Brasseur de Bourbourg the cocoa used for monetary purposes received the name of patlachté or patasté, of patle, that meant change. 
Another commodity of payment was the gold Moctezuma's Eagles, or Quauhtli, reserved for important payments. These Tepuzque pesos did not have a uniform value, but varied according to their weight and law. They usually contained copper alloy, and in 1536 their parity was fixed with the account currency at 272 maravedies, which implied a law of 13.6 carats. With it the tomin of gold was equivalent to the Castilian real of silver, with a value of 34 maravedies. The Cabildo of Mexico tried to mint pieces of this species with values of one, two and four gold tomines. ${ }^{4}$

The meagre of the circulating currency in areas of Spanish America in the 17th century, despite the great production, appreciated the value of minted money, favouring those who received salaries and a credit system, based on lenders, who flocked to the influential creoles and even the Crown, as happened in 1689, when the viceroy of New Spain was asked to hire a loan of one and a half million pesos, at an interest of $5 \%$ per annum, to be charged for the funds that would be obtained by the reduction of the mercies and the Derecho de Cobos, which consisted of $1.5 \%$ of the molten metal. The lack of circulation covered a special gravity in territories with scarce gull production and without an important trade or production, where, in addition to its scarcity, it was added on many occasions the poor quality of the circulating currency. These problems were exacerbated by the obligatory referral to the Peninsula of the little metal rehearsed and of large sums of money in minted currency, both in the concept of payments to the Real Hacienda as in remittances sent by private individuals and merchants, or even by the Religious orders.

\section{Indigenous monetary system}

Together with this monetary system that we could call peninsular, studied by Torre Rangel, ${ }^{5}$ there will also coexist an indigenous monetary system and a popular monetary system. The pre-Hispanic indigenous monetary system remained in effect for centuries, which was adjusted to law, since the Leyes de Indias allowed the Indians to be governed by their own right, if it was not contrary to the Catholic faith. To this survival, which crossed the limits of the Indians Republics to enter in the sphere of the economic life of the Spaniards, also contributed the lack of small pieces. Cavieres ${ }^{6}$ gathers the thesis of Romano that there would not have existed a real account currency in the Spanish Kingdoms of Indies economy and that the moneda de la tierra, literally land currency, would have been more than the set of products more characteristic of each area, and that in the same eighteenth century was discussed if the currency in circulation was sufficient for the needs of the great trade. The parity of these commodity money with the current metallic currency was fixed by the viceroys and cabildos, and especially the changes of some of them, like the cocoa beans, the coca leaf or the blankets, being the latter used for the payment of the locks fasteners of mines. We know that, in 1689 , the value of these mantas, blankets, in the Yucatan Governorate was four and a half pesos each, and that the pieces of cloth were the common currency in Paraguay and Tucumán. Other objects used as forms of payment were iron hooks or pearls, used in Venezuela and Margarita Island. The pre-Hispanic system was based on the chopping boards, T-shaped metal parts, the gold powder contained in the transparent cannons of bird feathers, in cocoa beans, cotton objects or shells. ${ }^{1}$ In the Mexican area the Indians used for their trade relations with the Spaniards those chopping boards, hatchets or chisels made with copper sheets. Its fragility, and the fact that they have been found in groups of up to a hundred in the burials of the area of Oaxaca, have made that some authors consider that they had the function of commodity money, opinion discussed by others.
The grains of many types of cocoa were used as currency in New Spain, Yucatan and Guatemala, and even were falsified filling them with soil, and although an ordinance of 1527 forbade its monetary use, in 1536 it was again allowed. Between the Spaniards two hundred grains amounted to a real. Cobarrubias ${ }^{8}$ affirms that the year 1555 can be considered as the one in which the Crown fully accepted the use of cocoa for the frequent payments, given that by order of June $17^{\text {th }}$, it was regulated that 140 berries of cocoa were equal to a silver real, and that with it avoided the oscillations of its value in the trade often and the contrast between their valuation between wholesale and retail trade. According to Chacón ${ }^{9}$ between the late $17^{\text {th }}$ and early $18^{\text {th }}$ centuries there was a difficult economic situation that led to the absence of silver currency for internal transactions in Costa Rica, so it was requested and obtained in 1709 the authorization of the Crown for the use cocoa as monetary commodity. For the study of pre monetary objects used for transactions in the area of Tawantinsuyu or Inca Empire we refer to the magnificent study of Ginocchio. ${ }^{10}$

These forms of payment had the serious drawback of the large alterations in their value, and they could not be considered really currency, since they did not meet the common measure of value requirement. The so-called rescates, bailouts, were carried out in these systems. These land currencies were also sometimes goods and products manufactured in Europe, as is the case of the domestic animals or the so-called cuchillos de rescate, rescue knives. ${ }^{4}$ The great diversity that exists among these commodities money and its different valuation made it aware of its value was essential for the trade.

As Burzio ${ }^{11}$ stated, the land currencies were habitual in the particular deals and in the trade in the sixteenth centuries, part of the seventeenth and in some regions in the eighteenth, and that in the part of the later constituted Viceroyalty of Río de la Plata the sealed currency in progress, consisting mainly of currency cob coins of Potosi, was of notorious scarcity, as can be seen in the Minutes of the cabildos of Asunción of Paraguay, Corrientes, Santa Fe or Córdoba. It also happened in other regions, citing cocoa in New Spain, coca in Peru, pearls and emeralds in Venezuela, Ave Rica feathers in Guatemala, yerba mate tea, and tobacco and cotton canvas in Paraguay. For the transactions, the Spaniards also used the cotton varas, used as currency in all the tropical and subtropical America, from the current Mexico to the Andes and from the Atlantic to the Pacific, and with a value of two real each vara, 0.8359 meters, in the area of Río de la Plata in a late date. The Aztecs used the so-called small blankets, while in other areas they were counted by canvas varas with a more or less uniform width and with a variable value according to their quality, although there was a standard value, known as lienzo común, common canvas.

According to Aranda and Bello, ${ }^{12}$ in the $17^{\text {th }}$ century among the Nahua groups of the Central Antiplano, the white or quauchtli blankets, mantas blancas, were the main currency in circulation, according to León Pinelo. The blankets were used as the main currency in the Mexica markets, and the newly married men gave these quauchtli to their wives to acquire in the market food, chilies, salt or firewood. The quauchtli were, for these authors, a convenient way of accumulating wealth. As told, other land currencies were the tobacco beams, which at the time of Phillip III received the official money qualification in the areas of Plata, Tucumán and Paraguay, the cocoa beans, which in the current Venezuela were counted at 140 the real in 1555, and in 1590 a gold escudo was worth 1,600, and the yerba mate arroba, over $11.502 \mathrm{~kg}$, in Paraguay, with a value of twelve reales. In the city of Córdoba, in the governorate of Tucumán, goats were used as a currency. ${ }^{13}$ 
At present Venezuelan coastline, the abundance of pearls made it scam for monetary purposes, and thus was decided by the Cabildo of Caracas, and its use was perpetuated until the sales of cocoa began to be charged in Mexican silver currency in the $17^{\text {th }}$ century. Beltrán ${ }^{14}$ stated that at the end of the $16^{\text {th }}$ century in Buenos Aires there was no metallic currency, so it was established equivalences of the various goods, as in Paraguay and Peru, and thus a calf of one year worth two varas of cotton canvas, one spurs four varas and one pair of boots two.

\section{The Rio de la plata area}

We find in this territory the so-called moneda o peso de la tierra, in commodities, which circulated in the provinces of Paraguay, Tucumán and Río de la Plata, with just estimation, given by a Cédula of 10 of October of $1618,{ }^{6}$ of six reales of silver, one peso or dollar, for the payment of tariffs and taxes of Indians. Only at the beginning of the seventeenth century began to be currents the silver coined coins. In the present-day Paraguay, the extreme shortage of minted currency made the payments undertake in metallic objects imported from Europe, such as hooks, rescue knives, chisels and cuñas, wedges, de ayunque. The metal received or recycled was transformed by the blacksmiths into these objects, leaving part of the metal in its power as payment of its work, two ounces per pound worked. In the area of silver, therefore, the blacksmiths functioned as rudimentary mints. The currency known as anzuelo de mayas, hook of nets, or de rescate, rescue, was created by the governor of Paraguay Domingo de Yrala in 1511, made the first with the steel nets of the soldiers and a value of a maravedi and the second with a value five times higher.

The circulation of the substitute goods of the currency coined in the area of the present Paraguay has been studied by Pusineri Scala, ${ }^{15}$ using the documentation preserved in the National Archive of Asunción. A curious receipt of 1673, signed by an Indian named Mateo, claims that he received from Treasurer Diego de Yegros twenty five patacones in tobacco, which amounted to one hundred and fifty libras, $0.460 \mathrm{gr}$ each libra or Castilian pound, or six arrobas. The payments on these goods to the Real Hacienda did not stop causing problems. Thus, in 1677, in a letter of $17^{\text {th }}$ May of the accountant Pedro de Alvarado and the Treasurer Francisco de Quintana, officers of the Real Hacienda of the provinces of Paraguay and Rio de la Plata, the official treasurer of Asunción, Captain Diego de Yegros, said that these commodities money or pesos huecos were a serious impairment for the Real Hacienda, since three of those pesos huecos were converted into a single current silver peso in the provinces of Peru, where they had scarce economic output. In order to avoid this depreciation, it had been agreed that they should be moved to Santa Fe and that they would be sold out for public sale and auctioned off. In successive documents of the same Archive are shown the quantities sent for such auction, 2.578 arrobas and two libras of yerba, 8 arrobas and 16 libras of sugar and 1.143 arrobas and 16 libras of tobacco, which should be necessarily paid in pesos of current silver pieces of eight reales. The arroba de yerba, according to the documents preserved in the Archivo General de General de Corrientes and in the Asunción, had a value of two silver pesos in those cities of San Juan de Vera de las Siete Corrientes and in Asunción.

This yerba that was produced in Paraguay should, according to several royal certificates of the year 1680, taxed if it was taken for

${ }^{6}$ Recopilación de las Leyes de los Reinos de las Indias, L. IV, Tít. XXIV, Ley VII, Que las monedas de la tierra en el Paraguay sean especies, y valgan á razon de seis reales de plata el peso, Felipe III, Madrid, 10 de octubre de 1618 consumption in other cities and provinces, citing Peru, Tucumán and Santa Fe de la Vera Cruz. Another example of commodity money collected by Pusineri is that of a boat that capsized on the way from Paraguay to Santa Fe, transporting lienzo de la tierra de Ley belonging to the Cajas Reales. The use of these currencies was extended, in addition to the daily transactions and the payment of the taxes, to the postal service. The royal protection to the Indians of the Paraguayan area is shown in an instruction sent to the Governor General of the province, don Gregorio Bazán de Pedraza, on February $18^{\text {th }}, 1708$, urging not to take against the will of them baggage, but with the consideration of his fair price. It also reminds him the prohibition of the Royal officers to take money from the Cajas of the Indian communities, which according to this instruction had sometimes occurred.

The chronic shortage of minted currency in the territory led to the request to the monarch in a Cabildo of Asunción Act dated February $18^{\text {th }} 1727$, to have the grace of the provincial currency in the province, as happened in other kingdoms. The reason asserted for the request was that there was no silver currency, but only monedas de la tierra, such as yerba, tobacco and others referred to in the Recopilación, which could only be used in that province, by exchanges and swap. A similar request was made by the Cabildo in an Act dated June $16^{\text {th }}, 1732$. The state of economic hardship is also included in the letter relation of the Jesuit Father José Cardiel of 1747. The valuation that gives of the $y e r b a$, the principal of the commodity money used, is of two pesos the arroba, and the same one had the arroba of tobacco. The tributes owed to the King by the Indians were paid in commodity money and they ascended to a peso, and of them were exempted the caciques and their firstborn, those over the age of fifty years, the under eighteen and twelve Indians for the service of the Church, in the Fathers' home and their orchard. In addition to the lack of milled circulating, the fact that the monedas de la tierra were sent to other neighbouring provinces, with little or no benefit for those who transported them, that they had to satisfy for them, in addition to the freight carriers, the fees that taxed them. These fees were also to be satisfied in the scarce metallic currency in the port of Santa Fe, and the carriers, in lack of it, had to sell their gender to the neighbours at very low cost. This made good part of the yerba is revert by land, much slower, to Buenos Aires. The political and economic integration enjoyed by the Viceroyalty of Peru in the past centuries, especially in the seventeenth one, was reduced in the eighteenth. To this they contributed the creation of two new Viceroyalties, Nueva Granada in 1717 and definitively in 1739, and Rio de la Plata in 1776, and the increase of the tax pressure, that made the partial recovery of the mining production and the increase of the population not translated into restructuring of previous economic and trade structures. ${ }^{16}$

The opening to the free trade of the port of Buenos Aires in 1778 increased the entry of foreign goods, in competition with the Indian textiles centres, and it was an important output of precious metals abroad. If previously the Peruvian coast had been the supplier of textiles and agricultural and tropical products of Upper Peru, at present Bolivia, in exchange for Potosi silver currency, from this moment the exchanges were made with foreign fabrics, altering all the relations Commercials of the Andean space. In Upper Peru the mining production and the high official monetary manufacture created a great monetary offer, much higher than its agricultural production, which allowed the contribution of currency to the commercial circuits of long distance. Also, an important part of this monetary surplus was diverted to the Rio de la Plata by the systems of tax collection, 
collection and rent. The axis La Paz-Potosí, on the Camino Real that joined Lima with Buenos Aires, was according to Santamaría ${ }^{17}$ the main channel of circulation of imported goods and of silver currency, articulating different commercial routes in different stations of its route.

The monetary surplus was a strong incentive for the acquisition of European goods, both legal and contraband, but also for the goods in the nearby territories, such as the purchase of spirits and wines for consumption in Potosí and La Paz. Towards 1794, of the amount purchased affected alcabalas, taxes, almost nine tenths came from Cuzco, Lima, Quito, Moquegua, Arequipa and Tucumán. It is very interesting in Santamaría's article the performing study of the role of the curacas, Indian authorities, as intermediaries of the communal Indians Republics and the distributing tariffs up to their abolition in 1781. As the contemporary author Juan de Santa Gertrudis affirmed, the whole of Peru did not circulate or there wasn't copper currency.

Yerba mate, commodity money in many areas, which previously referred to Alto Peru, began to be exported directly to Buenos Aires, and the farmers of the Plata basin began to send their products in the same direction, and thus displaced the old supplier areas. Trade between Buenos Aires and Chile had also increased considerably. The exit of silver was oriented towards the port of Buenos Aires, depriving of the Andean regions of currency and wasting the traders Lima control of the Ultramarine trade.

\section{Popular currency}

The other system, that Torre Rangel ${ }^{5}$ has called popular, has its origin also in the necessities of currency for lack of small currency of copper. Within the same stand out four figures, which are the tlacos, the pilones, the raw metal and the libranzas, promissory notes? The tlacos and pilones were of popular creation, to meet the need for fractional currency, and consisted of irregular pieces of shapes and weights other than bone, wood and, mainly, copper, in circulation even after the independence of the Ibero-American republics. This popular currency, created in principle by traders in detail for small payments, was adopted in the mining and agricultural farms, so that the workers and day labourers would be supplied in the stores of the same ones, known as Tiendas de Raya. ${ }^{18}$ The word tlaco derives apparently from the Aztec term tlahco, and means half, since it was traditionally half of a quartile. The tlaco was divided into two pilones, with a value of $1 / 16$ of silver real, and which also received according to the place where they circulated the names of cacharpas, batiches or jolas. Fernandez de Lizardi ${ }^{19}$ stated that the origin of the term pilón was in the rolls or piloncillo cones of sugar that was given to those who in the pulperias cacahueterias, velerias and other houses of commerce acquired half real merchandise.

The name was later generalized, knowing everything that was given for free or as a gift to acquire something. Later he was given a fixed value, with the division of the real in two half, four quarters and eight tlacos, and each tlaco in two halves and each one of them in two pilones. Each pilón also equalled six cocoa grains, in order to supply in the trade often the lack of small currency. Later, with the issuance of small copper coins of value of $1 / 2$ tlaco, or eighth, they were given the name of pilones.

Unlike for the indigenous monetary system, this circulating currency was born and lived for many centuries outside the law, even if the authorities knew of its existence and tolerated its circulation. We will have to wait until the eighteenth century so that the tlacos and pilones were regulated, and their parities were fixed with other currencies. But even after the recovery of copper coinage by the Monarchy in the Spanish Kingdoms of the Indies, they will continue to circulate for small operations during the nineteenth century. The use of not coined silver and gold as a currency was widespread and long existence in the Spanish Indies. Persecuted by the laws and by the rulers, being of metal that hadn't paid tariffs and therefore that it had not taxed to the Crown and escaped to its control, its circulation reached its greater expansion in the second half of the seventeenth century, to diminish, but not to disappear, in the next century. In the Archivo General de Asunción retains a side of the Treasurer Diego de Yegros, dated January $14^{\text {th }}, 1680$, forbidding, under penalty of apprehension and punishment for the holders, the holding of gold and silver unmarked in the province of Paraguay. The Libranza is a different figure from the bills of exchange born to the heat of the uses of the trade, and it is a promissory note seen to pay to its presentation and used for all type of payments and collections, which had its maximum expansion in the eighteenth century.

\section{Spanish asia and pacific area}

Upon the arrival of the Spaniards to the Philippine archipelago, the circulating currency was made up of cash, small copper coins whipped in China, the cowries and rice. ${ }^{20}$ Still in the nineteenth century, Davis Island based its economy on the collection of these shells, called in the Philippines sigeys or sigayes, to send them to India and Siam where they served as currency. ${ }^{21}$ Diaz Arenas, ${ }^{22}$ called them sigáy, and those obtained in Sibuyan, Lucban and other places were sold in large quantities to foreigners for their monetary use in the Hindu subcontinent. We had to discard the large shells and the low weight for being brittle, choosing those that had some strength, and those of Zebu and other points had less value. Mas ${ }^{23}$ asserted that before the arrival of the Spaniards gold was used in the sales, weighing the metal powder or nuggets on a scale called tálaro. The pesa mayor, equivalent to ten reales of silver-of 1842-, was called tael, dividing in two tingas, these in two sapahas and each one of them in two sangsaga, with the weight of a fijolito of that name. Along with the minting coin, of better or worse quality, monedas de la tierra were also used in the islands. In the fixation on December $5^{\text {th }}, 1740$ of the tribute to pay it is stipulated that the amount was often castellanos, or their equivalence in certain products, which received their valuation.

These products that could be used for payment were the blankets of abaca, about six meters long and one metre and a half wide, valued at three reales. Six kilograms of ropes of these same fibres were valued in two reales. The clothes of cotton or lampotes are of approximately six meters length and one of wide received estimation for tribute effects of four reales. Also could be used as payment the thick blankets of cotton. ${ }^{24}$ The small change currency was scarce in the Archipelago, so the pesos and half pesos were cut into pieces. This fractional necessity currency was known with the Tagalog names of kahati the two reales and sikapat the simple real ones, whereas in Spanish they met as cut currency. These fractions were marked in Manila with a stamp of their value, but did not indicate their weight in metal, so it was very exposed to slim. ${ }^{25}$

In the Spanish Micronesia, Patacsil ${ }^{26}$ claims that bartering was the habitual practice of trade between the native chamorros of the Marianas until the arrival of the Spaniards in the $16^{\text {th }}$ century. After the establishment of the first mission in 1668 by Fray Diego Luis de San Vitores, it was common for the Nao de la China to make a stop in the port of Agaña, to disembark the religious and officials of the 
administration and located for the payment of the functioning the soldiers and stipends for the missionaries. Since there were no shops in the Marianas during these early years, according to Patacsil the soldiers normally used it to gamble in the game. At the end of the $17^{\text {th }}$ and early $18^{\text {th }}$ century the local population was normally paid in commodities, such as tobacco leaves from the Philippines, which were a daily wage of one tenth of a real or the eighteenth part of a peso. For this reason, according to Patacsil, a worker needed to work from four to six months to acquire trousers of the cheapest material, valued between six and eight reales.

In the early eighteenth century the Higher Government of Manila issued a document recommending the introduction of currency in the Marianas, since the shortage of circulating was the cause of a series of problems that needed solutions. The Vice Provincial of the missions of the islands, Gerardo Bowens, wondered in 1706 in relation to this document how they could correct the injustices with the introduction of currency, and believed that what would have to be done was not to compensate them with currency, but with articles such as bolosmachetes-, carajayes -iron plates-, and other goods and ornaments that could be used by them.

\section{Conclusion}

As discussed in this article, the use of this commodity money, or alternative ways of payment, was due both to the maintenance of pre-Hispanic monetary systems and to the shortage of currency in certain areas of the Spanish Indies. Despite the fact that in theory all the Ultramarine territories of the Crown were considered formally equal and attempted to endow the less graceful with currency through the Situados and the increase of trade, there were areas that had to resort to monedas de la tierra for their daily economic development. For centuries the traders and silver merchants were contrary to the emission of fractional currency, and for more than two centuries the coining of copper currency was purely symbolic in the Spanish America. It will be in the eighteenth century when the Monarchy, aware of the problems derived from the shortage of small change, enhances the coinage of smaller module currency, simple reales, medium and fourth ones, and it begun to coin systematically copper currency. Despite all the efforts, in the largest Monetary and Fiscal Union known to Humanity, the Hispanic Monarchy, these commodities money were used in certain areas until their debacle at the beginning of the nineteenth century. ${ }^{27}$

\section{Acknowledgments}

None.

\section{Conflicts of interest}

Author declares no conflicts of interest.

\section{References}

1. Carson Brevoort J. Early Spanish \& Portuguese Coinage in America. Boston; 1885 .

2. Gil Farrés O. Historia de la moneda española. Madrid; 1976.

3. Mar A del. The science of Money. London; 1885.

4. Céspedes del Castillo G. Las cecas indianas en 1536-1825. In: Anes y Álvarez De Castrillón G, Céspedes del Castillo G, editor. Las Casas de Moneda en los Reinos de Indias Vol I. Madrid; 1996.
5. Torre Rangel JA. Algunas observaciones sobre el derecho monetario en la Nueva España. México. 1994. p. 141-163.

6. Cavieres Figueroa E. Servir al soberano sin detrimento del vasallo, El comercio hispano colonial y el sector mercantil de Santiago de Chile en el siglo XVIII. Valparaíso; 2003.

7. Dinero Exótico. Una nueva colección del Museo Arqueológico Nacional, Colección Cayón. Madrid: Catálogo de la exposición; 2001.

8. Covarrubias JE. La moneda de cobre en México, 1760-1842, un problema administrativo. México; 2000.

9. Chacón Hidalgo MB. El cacao como moneda oficial en la Costa Rica del siglo XVIII. NVMISMA n ${ }^{\circ} 252$; 2008. p. 137-147.

10. Ginocchio MF. Medios de cambio en el Perú prehispánico. NVMISMA $n^{o}$ 102-107; 1970. p. 9-54.

11. Burzio HF. Orígenes de la moneda americana del periodo hispánico. NVMISMA nº147-149; 1977. p. 153-163.

12. Aranda Kilian L, Bello Chávez G. La moneda tejida: manta como moneda en el mundo prehispánico. NVMISMA, $\mathrm{n}^{\circ}$ 247, enero-diciembre 2003, p. 39-53.

13. Romero E. Historia Económica del Perú. Lima: 2006.

14. Beltrán Martínez A. Numismática hispanoamericana. NVMISMA. $\mathrm{n}^{\circ}$ 156-161; 1979. p. 157-174.

15. Pusinelli Scala CA. Historia de la moneda paraguaya. Siglos XVI al XIX, Asunción, 1992.

16. Pérez Herrero P. Comercio y Mercados en América Latina Colonial. Madrid: Colección Realidades Americanas, Mapfre; 1992.

17. Santamaría DJ. Intercambios comerciales internos en el Alto Perú colonial tardío. Revista Complutense de Historia de América 22. Madrid: $\mathrm{UCM} ; 1996$.

18. Agraz JR. Tlacos, Pilones y Tiendas de raya en Sonora en el siglo XIX. Memoria del VIII Simposio de Historia y Antropología. Mexico: Universidad de Sonora; 1984. p. 146-156.

19. Fernández de Lizardi JJ. El Periquillo Sarniento, por el Pensador Mexicano. Tomo III $4^{\mathrm{a}}$ ed. México; 1842. $229 \mathrm{p}$.

20. Malo de Luque E. Historia Política de los Establecimientos Ultramarinos de las Naciones Europeas. Madrid: Tomo V; 1790.

21. Buzeta M, Bravo F. Diccionario Geográfico, Estadístico, Histórico de las Islas Filipinas. Madrid; 1831.

22. Díaz Arenas R. Memorias históricas y estadísticas de Filipinas $y$ particularmente de la grande isla de Luzón $10^{\text {a entrega. Manila; } 1850 .}$

23. Mas y de Sanz S. Informe sobre el estado de las Islas Filipinas en 1842. Madrid: Tomo I; 1843. p. 24.

24. Arcilla SJ. An Introduction to Philippine History. Manila $4^{\mathrm{a}}$ ed, $8^{\mathrm{a}}$ reimpresión; 2003.

25. Pardo de Tavera TH. Una memoria de Anda y Salazar. Manila; 1899.

26. Patacsil PE. Coinage in Guam during the Spanish era. Chapel Hill NC, Professional Press; 1998

27. Vázquez Pando FA. Algunas observaciones sobre el derecho monetario de la Nueva España. Memoria del X Congreso del Instituto Internacional de Historia del Derecho Indiano. 1995. p. 1675-1706. 